\title{
An Exploratory Study about Culture and Marketing Strategy
}

\author{
Adam Acar \\ Kobe City University of Foreign Studies, Japan \\ Jeevan Madhusanka Premasara \\ International University of Japan, Japan \\ Joshua Smith Glen \\ International University of Japan, Japan
}

\begin{abstract}
This study has empirically examined how culture influence marketing strategy choice. By presenting opposing marketing strategies in a bi-polar continuum and correlating selected marketing strategies with country scores on Hofstede's culture dimensions, this research established a connection between cultural values and marketing strategy preferences. The results have shown that managers from individualistic cultures tend to chose differentiation and niche marketing strategies over mass marketing strategies. Additionally, it was found that most Asians prefer Blue Ocean strategy versus direct competition strategy.
\end{abstract}

Keywords: Culture, Marketing strategy 


\section{Introduction}

"The way of the sage is to act but not to compete"

\section{Lao-tse}

After listing a number of major marketing and product strategy failures of MNCs, Kim and Mauborgne (1987) address the importance of understanding local cultures in order to succeed in the global arena. By the same token, Doole and Lowe (2003) also claim that pre-existing social and cultural complexities in local markets will always be challenging for marketing practitioners during the strategic analysis and international market planning phases. The authors base their judgments on the mere fact that people from different countries think and act differently in similar conditions mostly because of variations in religion, language, aesthetic perception, law and politics, material culture, social organizations, education, values and beliefs. While it becomes obvious that culture impacts marketing practices, the question still remains to be answered is how culture influences overall marketing strategy or what aspects of culture come into play when developing long term marketing strategies.

So far, only a few studies explored the relationship between culture and marketing strategy which can be linked to the problem with the definition of the concept. Today, there is no clear-cut definition of "marketing strategy" as each academic paper provides a different one. Since it is hard to define, it naturally becomes difficult to operationalize both strategy and marketing strategy. For instance, there is no consensus on if marketing strategy should be treated as an individual choice or an organizational decision, measured by observations or self reported measures and employ attitudinal items or behavioral measures. Despite the fact that there is some gray area in the operationalization, majority of the past studies followed the format of questionnaire survey with foreign company managers about the past marketing operations (Shah et al., 2000 (USA); Fongsuwan, 1999 (Thailand); Ekerete, 2001 (Nigeria)).We claim that contacting with business executives and asking them what type of marketing techniques they used in the past might not give us the clear picture of how culture impacts strategy or the relationship between country of origin and marketing practices. This is mostly because of the interference of several situational factors such as category characteristics (e.g. service vs. manufacturing), organizational culture (e.g. innovative vs. traditional), company structure (e.g. multinational vs. individual), company size (small vs. large) and economic conjuncture (developing vs. developed economies) during marketing managers` decision making process. Thus, instead of asking what practices have been done in the past, it might be more appropriate to present opposing marketing strategies in a bipolar continuum and ask respondents to indicate their preference among two available options in a general situation.

By addressing the past methodological problems and using a creative approach to the measurement of strategy, this study aims to fill the literature gap about the relationship between cultural dimensions and marketing strategy. With the help of this research, we can understand how an individual's local culture predicts his/her marketing strategy decision. Additionally, the scope of this study was marketing 
strategy tendencies of Asian business executives in particular. Since most of the participants were Asian, the results provided valuable insights about what kind of marketing strategies are preferred in Asia. Given that Asia has been leading the recovery of the world out of the recession and has been gaining more economic and political power in the world stage, the results would be enormously helpful for the marketing practitioners both in and out of Asia.

\section{Literature Review}

\section{Culture and Strategy}

Culture can be summarized as a collection of morals, laws, beliefs and customs that forms the behavior or structures how a person perceives the world. Cultural norms are passed on by older members to young members of a society and shared by almost all (Carrol, 1982). Culture acts as guidance for human behavior and creates social groups which are different from each other which react differently to their environment (Adler, 2002). Culture in business organization can be considered as the shared mental software of the people in an organization. "All business today is global and those individual businesses. Firms, industries who understand the new rules of doing business in world economy will prosper; those that do not will perish" (Adler, 2002). The global competition has forced businesses to think differently. Today's global and multinational Business practices has become very competitive and it is of utmost importance to learn about different cultures, monitor ongoing changes in culture and understand the impact of culture on business practices (Kanungo, 2006; Yip, 1995). A strong organizational culture is likely to shape the company's strategic decisions and moves. Such companies have culture driven bias on strategy making and strategic moves (Thompson, 2001). Cultural differences are based on to what extent people's thinking can be changed: how people dominate and take control of environment, individualistic and group behaviors, how people like doing things and how the space is seen in relation to privacy and orientation towards time such as present, past or future (Adler, 2002). These factors can be used to explain how individuals manage different situation based on a strategy influenced by their own cultures.

\section{Culture and Marketing Strategy}

A considerable amount of literature has been written on culture and consumer behavior, culture and advertising, as well as culture and market orientation (de Mooij, 2004). Much of the literature in the past has been written with goal of explaining such cultural influence on strategy and how to design different strategies to fit different cultures. Hofstede (1991) stated that culture is "the collective mental programming of the people in an environment. Culture is not a characteristic of individuals; it encompasses a number of people who were conditioned by the same education and life experience." Hawkins et al. (1986) state that the idea of how different cultural variations influence marketing strategy state that the cultural aspects of language, 
demographics, nonverbal communication, and values influence consumer behavior, consumer behavior in turn influences the marketing strategy making process.

On top of differences in culture, Yoon and Lee (2005) pointed out in their paper that there are considerable differences in the definition of market-orientation. Yoon and Lee found that "market-oriented culture does not only affect firm performance directly, but does so indirectly by affecting the marketing strategy making process." Menon et al. (1999) defined the marketing strategy making (MSM) process as "a complex set of activities, processes, and routines involved in the design and execution of marketing plans." Menon et al.'s work describes the internal organizational culture and its effects on MSM as well as the MSM process and its effect on the firm performance in considerable detail. However, external influences on MSM were outside the scope of Menon et al.'s (1999) research.

When the study of culture's influence on marketing strategy is limited to Asia or Asian corporations, there is significantly less literature available on the subject. The National Identity, or NATID, Framework established by Keillor et al. (1996) went a long way in quantifying national identity differences based on a number of underlying factors. These factors include national heritage, cultural homogeneity, belief systems and consumer ethnocentrism. The practical purpose of developing such a framework is to identify and use cultural and national differences in a marketing context. Keillor et al.'s (1996) work included a comparison of Japan and Sweden. Their work was later supported by other work that had applied the NATID framework to a number of other East Asian countries including, South Korea, Taiwan, Thailand and Singapore (Phau and Chan, 2003). Phau and Chan's (2003) findings confirmed the usefulness of the NATID framework. However, this is a stark difference from earlier findings of Japanese and European companies that had achieved success through "expanding commonalities across national boundaries rather than focusing on customer differences based on nationalities" (Kotabe, 1990, italics added). According to Kotabe (1990), continual improvements in product and process innovation by Japanese firms lead to cost advantages. Standardization would lead to economies of scale and greater cost advantages. Abbeglen and Stalk (1986) explained that Japanese firms established a "winning cycle" by focusing on domestic markets first, perfecting and standardizing their product. Once momentum was built in the domestic market, firms would use their low cost advantage in other markets, essentially using a low price strategy. By comparing companies from Japan and Germany, Shah et al. (2000) point out that firms from differing countries use differing generic strategies. While their work shows the differences in strategy based on nationality of the firm's home country, it remains unclear how much of the difference in attributable to differences in culture or other factors.

\section{Marketing Strategy in Asia}

Business executives' individual decisions are influenced by their own national or local cultures (Hofstede, 1991) and there is a considerable cultural variation within Asia (Hofstede, 1980; Redding, 1990) which might be associated with differences in 
business strategies. Strategic choices are inherently affected by managers' national cultures (Hofstede, 1991), and surprisingly the Chinese managers, who have a widely noted cultural inclination to rely on informal ties, count on personal connections to succeed in achieving organizational goals (Chen, 1991). Real cultural differences exist in many Asian countries, within Asia, and between countries in Asia and elsewhere. It is presumed that national cultures influence business strategy through senior management beliefs and practices, authority and relationships, individualistic and group behavior aspects, personal exchange and finally decision-making (Fukuyama, 1995; Hamilton and Biggart, 1988; Redding, 1990; Westwood, 1997). The emergence and success of businesses such as the keiretsu in Japan, chaebol in South Korea, entrepreneurial firms in Taiwan, and Chinese family businesses in several Southeast Asian countries are examples of how culture impacts business formations.

Traditional Asian texts such as Sun Tzu's Art of War and their modern interpreters (Wee et al., 1996) are perceived to have a greater impact on Asian managers than the modern western strategy theory and concepts.

It can be argued that the Asian businesses implement strategy from a more intuitive, tradition-based and informal perspectives than the western managers, who adopt a rather contrasting systematic, scientific, and formal approaches (Chen, 2001). The underlying influence of strong and different cultures leads to form the Asian strategy to be a more manipulative, evolving, risk-seeking and results-oriented, in contrast to Western strategy, which is projected as a more planned, rigid, risk-avoiding and process-driven. Asian countries are considered to be "high-context", while the Western countries are considered to be more "low context" (Hall, 1976). It could be reasoned out that the influences made from basic culture and related factors on strategy, appear to be multifaceted and not direct, and felt more through the impacts on structures, authority associations and decision-making processes (Hofstede and Bond, 1984). The links between cultural values particularly of Confucian origin with economic growth are indications for many of these influences (Hofstede, 1980). Erramilli (1996) tested the impact of a country's 'national characteristics' on the subsidiary ownership policies of its multinational companies. According to these findings firms based in countries characterized by high power distance and high uncertainty avoidance will have a higher preference for majority or wholly owned subsidiaries. Erramilli (1996) continues that managers of multinational companies based in high power distance countries are more authoritarian, less agreeable to share decision-making with others, and therefore more likely to prefer wholly owned subsidiaries over shared-equity ventures.

\section{Theoretical Framework}

Hofstede (1980, p. 9) defines culture as "the collective programming of the mind that distinguishes the members of one group or category of people from the other groups." According to Hofstede (1980), most of the social scientists after the 50s tried to explain different nature of societal problems with different dimensions of the culture 
ranging from economic evolution to communication context. He also came up with five unique dimensions of the culture after analyzing 100,000 responses to his measures from 50 different countries between 1970 and 1980. Follow up studies validated his dimensions and during the initial period of 1980-1993, there were 1036 academic citations referring to his dimensions and his book (Sondergaard, 1994). Hofstede's (1980) five culture dimensions can be summarized as:

1) Power distance refers to the perception of power gap between different segments of the society such as elderly and youngsters, managers and subordinates and teachers and students. In societies where there is higher power distance, more inequality among people and less even distribution of economic wealth would be common.

2) Individualism/collectivism continuum represents the degree of individualistic versus collectivist tendencies that exist in each society. Individualistic societies put more value on achieving individual potential and personal freedom.

3) Uncertainty avoidance simply means refraining unambiguous situations. In uncertainty avoiding cultures, people cannot perform well in unstructured and unfamiliar conditions unlike some other cultures where ambiguity is part of a daily life.

4) Masculinity stands for the preference for competition and higher achievement in society. Masculine cultures tend to favor assertiveness and male dominance whereas feminine cultures value nurturing and caring.

5) Long term orientation is having future focus when making decisions. In longterm oriented societies, people put special emphasis on perseverance and frugality while saving one's face and relationships with others come first in short-term oriented societies.

Table 1 shows some of the past research related with Hofstede's culture dimensions and culturally driven risk taking, decision making and problem solving behaviors.

\section{Table 1 Studies about the Hofstede's Culture Dimensions and Business Practices}

\begin{tabular}{|l|l|}
\hline Authors & Study Content \\
\hline Hayton et al., 2002 & $\begin{array}{l}\text { Long term orientation and high uncertainty avoidance result } \\
\text { with reduced risk taking and entrepreneurial behavior. }\end{array}$ \\
\hline Ali, 1993 & Individualism is positively correlated with risk taking behavior. \\
\hline Chen and Li, 2005 & $\begin{array}{l}\text { People from collectivist countries tend to make uncooperative } \\
\text { business decisions in mixed-motive business environments and } \\
\text { show low levels of cooperation with foreigners. }\end{array}$ \\
\hline Smith et al., 1998 & $\begin{array}{l}\text { Collectivism and power distance directly impact the handling of } \\
\text { disagreements during the problem solving phase. }\end{array}$ \\
\hline Barkema et al., 1997 & $\begin{array}{l}\text { Uncertainty avoidance and long term orientation positively } \\
\text { impact the longevity of international joint ventures. }\end{array}$ \\
\hline
\end{tabular}


Specification of the concept: There are negative or positive relationships between certain cultural dimensions and certain types of marketing strategies.

Application of the concept: Company A which is located in country $\mathrm{X}$ where $\mathrm{Y}$ cultural dimension is high, likely to use $\mathrm{Z}$ type of marketing strategy.

Thus we hypothesize:

H1: National culture influences marketing strategy decisions. More specifically, we presume that some of the Hofstede's cultural dimensions will have a positive or negative relationship with some of the marketing strategy choices of participants from different countries.

\section{Methodology}

\section{Subjects}

The data was collected in February, 2010 via a password-protected online survey web site. All of the participants were graduate students at an International University in Japan majoring in MBA or E-Business programs. Approximately fifty three percent of the participants were males $(n=31$, mean age $=31)$ and $46 \%$ were females $(n=27$, mean age $=29$ ). There were a total of $59^{*}$ participants from 20 different countries from all around the world; 17 of them being Asian (Bangladesh, 2; China, 5; Costa Rica, 1 ; Finland, 1; France, 1; India, 6; Indonesia, 5; Japan, 4; Malaysia, 1; Mongolia, 4; Mexico, 1; Myanmar, 6; Philippines, 2; Senegal, 1; Sri Lanka, 3; Thailand, 3; USA, 2; Vietnam, 6; Unknown, 2). The study was announced to all students on the campus mailing list and there was no incentive for participation.

\section{Measures}

Based on the popular marketing strategy textbook "Marketing Strategies: A Decision Based Approach" (Walker, 2003) and some Harvard Business Review case studies we have developed 10 different scenarios where the respondents had to choose between two available options. Most marketing strategy books and business cases provide information about pros and cons of available options but do not necessarily identify a correct strategy or favor one strategy over another. With this in mind, we thought that the culture that the participants are coming from should influence the selection of available alternatives. Five-point semantic differential scale was used to measure the favorability of each option on individual level (e.g. follower $1 \ldots 2 \ldots 3$ (neutral)...4 $4 . .5$ leader). Some of the scenarios that were based on the textbook were mass marketing vs. niche marketing (Chapter 2), leader versus follower in market entry decisions (Chapter 8), and preference for competitive positioning versus 
blue ocean strategy (Chapter 6). We also asked about the preference for marketing control over distribution capacity (inspired by HBR business case; Ben Jerry's Japan Entry), focus on the local market versus overseas expansion (HBR Business Case; Hikma Pharmaceuticals) (Quelch and Root, 1997), following a farmer or hunter option when developing new technology products (McDonald, 1992).

Each respondent served as a representative of the country he/she belongs and were associated with five cultural dimension score that is available on www.geerthofstede.com. These scores then correlated with the individual's strategy choice for each scenario.

\section{Analysis and Findings}

Exploratory factor analysis with Varimax rotation was carried out to detect any underlying groupings among the 10 different strategy options in our study. The analysis revealed four major factors with Eigen values larger than 1, namely "competitive" (competitive strategy, differentiation, niche marketing), "opportunist" (partner capacity, opportunities), "leader" (leader, detailed research, don't affiliate), "hunter" (hunter, extend to foreign markets). The factors explained about $60.3 \%$ of the common variance in the data set also yielding statistically significant Bartlett's Test of Sphericity (Chi-Square = 64.68) (see Appendix I-II).

Table 2 Factor Loadings for Strategy Variables

\begin{tabular}{|c|c|c|c|c|}
\hline Item & Competitive & Opportunist & $\underline{\text { Leader }}$ & Hunter \\
\hline Blue ocean Strategy vs. Competitive Strategy & -0.65 & & & \\
\hline Cost leader vs. Differentiation Leader & 0.82 & & & \\
\hline $\begin{array}{l}\text { Mass marketing strategy vs. Niche Marketing } \\
\text { Strategy }\end{array}$ & 0.75 & & & \\
\hline $\begin{array}{l}\text { Control is important vs. Partner capacity is } \\
\text { important }\end{array}$ & & 0.70 & & \\
\hline Core Strengths vs. Opportunities & & 0.79 & & \\
\hline Affiliate vs. Don`t affiliate & & & 0.57 & \\
\hline Follower vs. Leader & & & 0.67 & \\
\hline Basic research vs. Detailed research & & & 0.65 & \\
\hline Farmer vs. Hunter & & & & 0.77 \\
\hline Extend to foreign markets vs. domestic market & & & & -0.65 \\
\hline
\end{tabular}

Following the factor analysis, Pearson Product Moment correlation coefficients were created by SPSS 15 (2008) for all of the strategy factors and the cultural dimensions. It was found that individualism was positively correlated with competitiveness $(\mathrm{r}=$ $.34, p<.05)$ and long term orientation was negatively correlated with hunter factor (extend to foreign markets, focus on currently cool products). Thus, H1 was 
supported. Although correlation does not mean causation, these findings made sense and were in line with our literature review.

Table 3 Correlations between Strategy Variables and Hofstede's Dimensions

\begin{tabular}{|c|c|c|c|c|c|c|c|c|c|}
\hline & 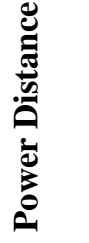 & 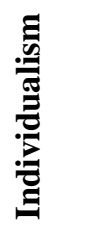 & 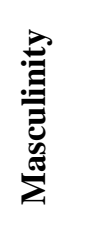 & 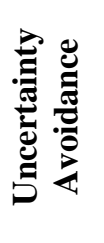 & 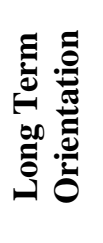 & 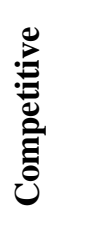 & 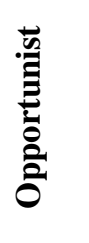 & & 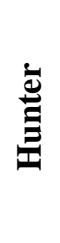 \\
\hline Power Distance & - & & & & & & & & \\
\hline \begin{tabular}{|l|} 
Individualism \\
\end{tabular} & -.588 & - & & & & & & & \\
\hline Masculinity & -.087 & .270 & - & & & & & & \\
\hline Uncertainty Avoidance & -.443 & .317 & .469 & - & & & & & \\
\hline Long Term Orientation & .125 & -.497 & .173 & -.214 & - & & & & \\
\hline Competitive & -.214 & .336 & .156 & .113 & -.021 & - & & & \\
\hline Opportunist & -.225 & .140 & -.087 & .266 & .008 & .000 & _ & & \\
\hline Leader & .191 & -.189 & .110 & -.005 & -.134 & .000 & .000 & - & \\
\hline Hunter & .087 & .045 & -.221 & .075 & -.546 & .000 & .000 & .000 & 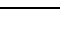 \\
\hline
\end{tabular}

Lastly, mean scores for each marketing strategy option were calculated to see overall strategic tendencies in Asia. Although most of the mean scores were clustered around the middle point (3) it was observed that preference for niche marketing, Blue Ocean Strategy and differentiation were higher when compared with mass marketing, competitive marketing and cost leadership.

\section{Conclusions}

In this simple yet conclusive study we have found that cultural dimensions are closely related with marketing strategy choices of business executives. It was observed that people from individualistic countries tend to choose differentiating and niche marketing strategies and people from long term orientation countries prefer focusing on the local market and take time to extend to new markets. These findings make perfect sense as long term orientation urges people to search for long term benefits 
and business practitioners from individualistic societies want to be different rather than creating a generic brand and covering the whole market.

Respondents from 17 different Asian countries did not necessarily favor any specific marketing strategy that is statistically significant. However, higher preference for Blue Ocean Strategy (Kim and Mauborghne, 2005) versus competitive strategy stood out. This should not be a surprise, given that Asian culture is believed to be heavily influenced by harmony-promoting thinkers like Lao Tse and Confucius. In societies where avoiding conflict is virtue, analyzing the details of competitive activity might not be any interest managers. Western business executives should keep in mind that when entering to new markets in Asia, their counterparts might lack the detailed information about the competitor.

\section{Limitations}

As the readers might already have noticed, this study did not measure cultural dimensions on the respondent level but just used country scores from Hofstede (1980) for each respondent. Although it might be difficult to measure culture individually, presuming that individuals from the same country would have exactly the same interpretation of their own culture and act exactly the same way in cross-cultural conditions can be misleading. Recognizing this as a limitation, we recommend future researchers to conduct similar studies with individual level measurements. Additionally, the two opposing ends of the strategy options, their definitions and available strategy choices might be perceived as subjective by some readers. Hopefully this study would be base for the future studies which can confirm reliability of our strategy choices and the definitions.

Finally, the sample size ( 35 subjects for the correlation analysis) and the nature of the sample are two serious limitations to this study. However, although the sample consisted of university students, the median age was about 30 and majority of the participants worked in high-level positions before joining the program. Regardless of the sample characteristics, these results should be just considered exploratory in nature and be replicated with larger samples and more rigorous analysis methods such as SEM or canonical correlation analysis. 


\section{Appendixes}

\section{Appendix I}

Factor Analysis Results: KMO and Bartlett's Test of Sphericity

\begin{tabular}{|lcr|}
\hline \multicolumn{2}{|l|}{ Kaiser-Meyer-Olkin Measure of Sampling Adequacy } & 0.489 \\
\hline Bartlett's Test of Sphericity & Approx. Chi-Square & 64.681 \\
& df & 45 \\
& Sig. & 0.029 \\
\hline
\end{tabular}

\section{Appendix II}

Total Variance Explained

\begin{tabular}{|l|c|c|c|c|c|c|}
\hline Component & \multicolumn{3}{|c|}{ Initial Eigenvalues } & \multicolumn{3}{c|}{ Rotation Sums of Squared Loadings } \\
\hline & Total & $\begin{array}{c}\text { \% of } \\
\text { Variance }\end{array}$ & $\begin{array}{c}\text { Cumulative } \\
\%\end{array}$ & Total & $\begin{array}{c}\text { \% of } \\
\text { Variance }\end{array}$ & $\begin{array}{c}\text { Cumulative } \\
\%\end{array}$ \\
\hline 1 & 1.970 & 19.696 & 19.696 & 1.878 & 18.783 & 18.783 \\
\hline 2 & 1.587 & 15.871 & 35.566 & 1.529 & 15.286 & 34.069 \\
\hline 3 & 1.359 & 13.587 & 49.153 & 1.361 & 13.611 & 47.680 \\
\hline 4 & 1.118 & 11.179 & 60.332 & 1.265 & 12.652 & 60.332 \\
\hline
\end{tabular}

Extraction Method: Principal Component Analysis. 


\section{References}

Abegglen, J.C. and Stalk, G. (1986), "The Japanese corporation as competitors", California Management Review, vol. 28, no. 3, pp. 9-27.

Adler, N.J. (2002), International Dimensions of Organizational Behavior, 4th ed., SouthWestern College Publishing, Cincinnati, Ohio.

Ali, A.J. (1993), "Decision-making style, individualism, and attitudes toward risk of Arab executives", International Studies of Management \& Organization, vol. 23, no. 3, pp. 53-73.

Barkema, H.G., Shenkar, O., Vermeulen, F. and Bell, J.H.J. (1997), "Working abroad, working with others: How firms learn to operate international joint ventures", Academy of Management Journal, vol. 40, no. 2, pp. 426-442.

Carrol, M.P. (1982), "Culture" in Freedman, J. (Ed.), Introduction to Sociology: A Canadian Focus Scarborough, Prentice- Hall, Ontario, pp. 19-40.

Chen, M. (1991), Asian Management Systems: Chinese, Japanese and Korean Styles of Business, Routledge, London.

de Mooij, M.K. (2004), Consumer Behavior and Culture: Consequences for Global Marketing and Advertising, Sage, Thousand Oaks, CA.

Doole, I. and Lowe, R. (2003), International Marketing Strategy, 3rd ed., International Thomson Business Press, London.

Ekerete, P.P. (2001), "The effects of culture on marketing strategies of multinational firms: A survey of selected multinationals corporations in Nigeria", Africa Study Monographs, vol. 22, no. 2 , pp. 93-101.

Erramilli, M.K. (1996), "Nationality and subsidiary ownership patterns in multinational corporations", Journal of International Business Studies, vol. 27, no. 2, pp. 225-248.

Fongsuwan, W. (1999), "A comparative study of international marketing strategies between Japanese, American and European multinational companies: Thailand 1997", CAS Discussion Paper No 25, Centre for ASEAN Studies, pp. 1-19.

Fukuyama, F. (1995), Trust: The Social Virtues and the Creation of Prosperity, Free Press, New York, NY.

Hall, E.T. (1976), Beyond Culture, Doubleday, New York, NY.

Hamilton, G.G. and Biggart, N.W. (1988), "Market, culture, and authority: A comparative analysis of management and organization in the Far East", American Journal of Sociology, vol. 94 , pp. 52-94.

Hawkins, D.I., Best, R.J. and Coney, K.A. (1986), Consumer Behavior: Implications for Marketing Strategy, 3rd ed., Business Publications, Plano, TX. 
Hayton, J.C., George, G. and Zahra, S.A. (2002), "National culture and entrepreneurship: A review of behavioral research", Entrepreneurship Theory and Practice, vol. 26, no. 4, pp. 3352.

Hofstede, G. (1980), Culture's Consequences: International Differences in Work-related Values, Sage, Thousand Oaks, CA.

Hofstede, G. (1991), Cultures and Organizations: Software of the Mind, McGraw-Hill, New York, NY.

Hofstede, G. and Bond, M.B. (1984), "Hofstede's culture dimensions: An independent validation using Rokeach's value survey", Journal of Cross-Cultural Psychology, vol. 15, no. 4, pp. 417-433.

Kanungo, R.P. (2006), "Cross culture and business practice: Are they coterminous or crossverging?" Cross Cultural Management: An International Journal, vol. 13, no. 1, pp. 23-31.

Keillor, B.D., Hult, G.T.M., Erffmeyer, R.C. and Babakus, E. (1996), "NATID: The development and application of a national identity measure for use in international marketing", Journal of International Marketing, vol. 4, no. 2, pp. 57-73.

Kim, W.C. and Mauborgne, R.A. (1987), "Cross-cultural strategies”, Journal of Business Strategy, vol. 7, no. 4, pp. 28-35.

Kim, W.C. and Mauborgne, R.A. (2005), "Blue ocean strategy: From theory to practice”, California Management Review, vol. 47, no. 3, pp. 105-121.

Kotabe, M. (1990), "Corporate product policy and innovative behavior of European and Japanese multinationals: An empirical investigation”, Journal of Marketing, vol. 54, no. 2, pp. 19-33.

McDonald, M.H.B. (1992), "Ten barriers to marketing planning", Journal of Business and Industrial Marketing, vol. 7, no. 1, pp. 5-18.

Menon, A, Bharadwaj S.G., Adidam P.T. and Edison S.W. (1999), "Antecedents and consequences of marketing strategy making: A model and a test", Journal of Marketing, vol. 63 , no. 2 , pp. $18-40$.

Phau, I. and Chan, K-W. (2003), "Targeting East Asian markets: A comparative study on national identity", Journal of Targeting, Management and Analysis for Marketing, vol. 12, no. 2, pp. 157-172.

Quelch, J.A. and Root, R. (1997), Hikma Pharmaceuticals, Harvard Business Publishing, Watertown, MA.

Redding, S.G. (1990), The Spirit of Chinese Capitalism, Walter de Gruyter, New York, NY.

Shah, A., Zeis, C., Ahmadian, A. and Regassa, H. (2000), "Strategies of gaining competitive advantage at the generic and business unit level: A study comparing American, Japanese and German companies operating in the United States", Multinational Business Review, vol. 8, no. 1, pp. 13-21. 
Smith, P.B., Dugan, S., Peterson, A.F. and Leung, W. (1998), "Individualism: Collectivism and the handling of disagreement: A 23 country study", International Journal of Intercultural Relations, vol. 22, no. 3, pp. 351-367.

Sondergaard, M. (1994), "Research note: Hofstede's consequences: A study of reviews, citations and replications", Organization Studies, vol. 15, no. 3, pp. 447-456.

Thompson, A.A., (2001), Crafting and Executing Strategy: Text and Readings, 12th ed., McGraw-Hill, New York, NY.

Walker, B. (2003), Marketing Strategy: A Decision Focused Approach, McGraw-Hill/Irwin, New York, NY.

Wee, C.H., Lee, K-S. and Bambang, W.H. (1996), Sun Tzu: War and Management: Application to Strategic Management and Thinking, Addison-Wesley, Boston, MA.

Westwood, R.I. (1997), "The impact of culture on business and management in Asia", in Safarian, A.E. and Dobson, W. (Eds.), The People Link: Human Resource Linkages across the Pacific: Hong Kong Bank of Canada Papers on Asia, vol. 3, University of Toronto Press, Toronto, pp. 13-72.

Yip, G.S. (1995), Total Global Strategy, Prentice Hall, Englewood Cliffs, NJ.

Yoon, S. and Lee, S. (2005), "Market-oriented culture and strategy: Are they synergistic?" Marketing Bulletin, vol.16, pp. 1-20. 